\title{
Beberapa Analisis Penerimaan Luar Negeri Indonesia
}

\author{
Oleh : Edy Suandi Hamid
}

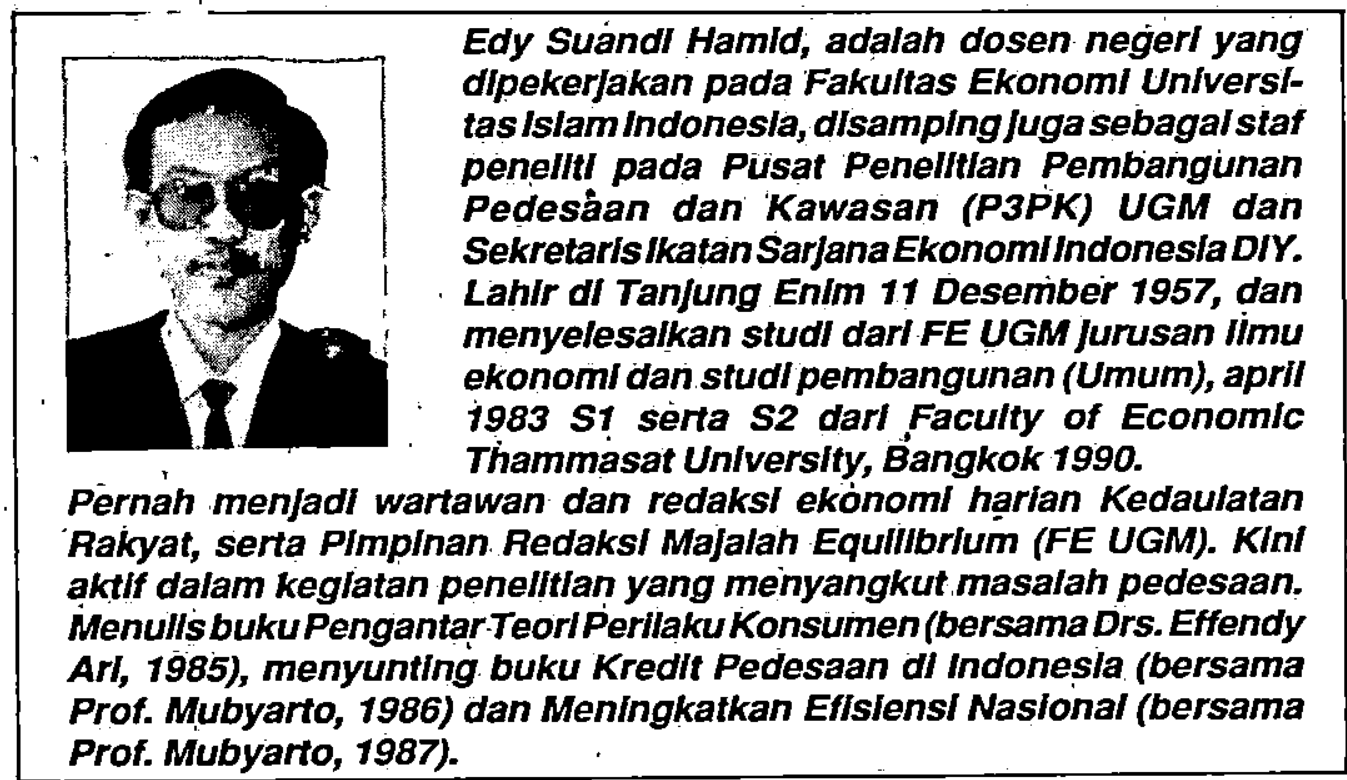

Pendahuluan

Salah satu aspek yang menarik untuk bahan kajian dalam Anggaran Pendapatan dan' Belanja Negara 1992/1993' adalah aspek bantuan atau hutang luar negeri. Dalam pos penerimaan pembangunan, tahun ini mengalami penurunan baik secara absolut , maupun secara relatif. dibandingkan tahun sebelumnya, yakni dari $R p$ 10,375 trilyun (1991/1992) menjadi Rp 9,6 trilyun (1992/1993) atau turun sebesar $7,4 \%$. Penurunan ini juga terjadi pada tahun sebelumnya, bahkan pada tahun." anggaran, 1991/1992 penurunan mencapai $8,1 \%$. Apakah penurunan ini akan menjadi 'kecenderungan pada tahun-tahun mendatang, ataukah hanya bersifat sementara, merupakan salah satu pertanyaan yang menarik untuk dianalisis. Namü demikian yang pasti adalah bahwa porsi penerimaan pembangunan (hutang luar negeri) terhadap total belanja atau anggaran pembangunan dalam tahun 1992/1993, seperti yang terjadi pada tahun anggaran 1991/1992, sudah semakin kecil.

Sebelum mengkaji secara.spesifik masalah bantuan luar negeri atau penerimaan pembangunan dalam APBN 1992/1993 maka ada baiknya untuk melihat dan menganalisis perkembangan pos ini sejak Pelita I, yang dikaitkan dengan beberapa prinsip dalam kebijak'sanaan fiskal kita, khususnya yang berkaitan dengan APBN ini, serta faktorfaktor yang mempengaruhinyạ. 
Anggaran B'elanja Seimbang Semu.

Dalam GBHN secara sngat jelas disuratkan bahwa bantuan luar negeri sifatnya hanya merupakan pelengkap dalam membiayai pembangunan nasional. Artinya, dana utama untuk belanja pembangunan tersebut harus lebih diutamakan bersumber pada potensi masyarakat Indonesia. Sumber dalam negeri ini jika dilihat dari anggaran pembangunan pemerintah dapat dilihat dari pos tabungan pemerintah, yakni selisih antara penerimaan dalam negeri dengan pengeluaran rutin pada RAPBN yang setiap tahunnya dijalankan mulai 1 April dan berakhir 31 Maret tahun berikutnya.

Namun demikian dalam perjalanan sejarah pembangunan kita yang tertuang dalam RAPBN tersebut, dapat diketahui sejak Pelita I' sampai sekarang, andil bantuan luar negeri terhadap anggaran pembangunan sangat berarti. Data yang ada menunjukkan, porsi' bantuan luar negeri (dilihat dari nilai rupiahnya) berkisar antara 24 hingga 81 persen dari total anggaran pembangunan. Bilangan tertinggi terjadi pada tahun terakhir Pelita IV (1988/89) dengan $81,5 \%$ serta awal Pelita I (1969/1970), yang mencapai $77 \%$. Artinya, sebanyak $81,5 \%$ dan $77 \%$ dari program pembangunan pemerintah pada tahun-tahun tersebut dibiayai oleh hutang luar negeri, dan hanya 18,5 dan $23 \%$ yang berasal dari tabungan pemerintah. Oleh karena itu sering dikemukakan bahwa anggaran belanja negara kita yang selalu berimbang ini sebagai anggaran belanja seimbang yang semu (artificial balance budget). Tanpa adanya pinjaman luar negeri tersebut, maka anggaran belanja negara selalu berada dalam keadaan defisit.

Dalam teori Ekonomi Makro dikatakan suatu anggaran belanja adalah seimbang apabila sisi penerimaan sama dengan sisi pengeluaran. Namun demikian, dalam sisi penerimaan ini tidak dimasukkan adanya unsur hutang. Oleh kaŕena itu, angka pengganda (multiplier) dari suatu anggaran berimbang adalah satu. Sebagai konsekuensinya, anggáran berimbang secara teoritik tidak akan melahirkan suatu efek kontraksi ataupun ekspansi, karena kedua efek ini akan meniadakan satu dengan lainnya atau sama besamya. Jika dikaitkan dengan APBN kita, maka APBN tersebut dapat dikatakan berimbang (menurut pengertian teoritik) apabila pos penerimaan dalam negeri sama dengan pengeluaran rutin ditambah pengeluaran pembangunan. Hal ini tidak terjadi dalam APBN kita, karena dimasukkannya unsur hutang luar negeri sebagai pos yang menghasilkan keseimbangan budget, sehingga dikatakan sebagai anggaran belanja berimbang semu tersebut.

Kaitan Bantuan Luar Negeri dan Penerimaan Minyak.

Jika diamati, maka pola bantuan luar negeri ini erat sekali kaitannya dengan perkembangan harga dan penerimaan minyak kita. Pada tahun-tahun di mana harga minyak meningkat, maka bantuan luar negeri secara proporsional terhadap anggaran pembangunan mengalami penurunan. Ini dapat dilihat misalnya tahun 1973/1974, di mana terjadi perang Arab-Israel yang membumbungkan harga minyak lebih tiga kali lipat dalam waktu setahun. Harga ekspor minyak bumi Indonesia pada bulan April 1973 hanya US\$ 3,73 per barrel, dan ini meningkat menjadi US $\$ 11,70$ pada bulan yang sama tahun berikutnya. Naiknya harga ekspor minyak ini telah menekan porsi bantuan luar negeri dan mencapai titik terendah. 
dalam tahun anggaran berikutnya, yakni $23,9 \%$ dari anggaran pembangunan pada tahun $1974 / 75$.

Keadaan demikian terulang dalam tahun-tahun awal dekade 1980-an. Dalam kurun waktu 1980-1985 harga èkspor minyak kita berkisar antara US\$27,50 hingga US $\$ 35$ per barrel. Harga tertinggi ini tercatat pada bulan Januari 1981. Sebaliknya, anjloknya harga minyak dunia membuat pinjaman luar negeri ini semakin besar, sebagaimana yang terjadi sejak medio 1980-an di mana harga minyak bertahan pada tingkat yang rendah. Penurunan tajam harga minyak ini terjadi

Tabel : 1

Nilai Ekspor Minyak Bumi dan Gas Alam $1969 / 70$ - 1991/92 (dalam juta US $\$$ )

\begin{tabular}{|c|c|c|c|c|}
\hline$T a h u n$ & $\begin{array}{c}\text { Minyak } \\
\text { bumi }\end{array}$ & Gas alam & Jumlah & $\begin{array}{l}\text { persentase } \\
\text { perubahan }\end{array}$ \\
\hline (1) & (2) & (3) & $(4)=(2+3)$ & (5) \\
\hline $1969 / 70$ & 384 & - & 384 & - \\
\hline $1970 / 7_{n} 1$ & 443 & - & 443 & $+\quad 15.4$ \\
\hline $1971 / 72$ & 590 & - & 590 & $+\quad 33.2$ \\
\hline $1972 / 73$ & 965 & - & 965 & $\begin{array}{r}63.6 \\
+\quad 6\end{array}$ \\
\hline $19.73 / 74$ & 1.708 & - & 1.708 & $+\quad 77,0$ \\
\hline $1974 / 75$ & 5.153 & - & 5.153 & +201.7 \\
\hline $1975 / 76$ & 5.273 & - & 5.273 & $+\quad 2,3$ \\
\hline $1976 / 77$ & 6.350 & - & 6.350 & $+\quad 20.4$ \\
\hline 1977178 & 7.191 & 162 & 7.353 & $+\quad 15.8$ \\
\hline $\begin{array}{l}1978 / 79 \\
1979 / 80\end{array}$ & $\begin{array}{r}6.858 \\
10.995\end{array}$ & $\begin{array}{r}516 \\
1.345\end{array}$ & $\begin{array}{r}7.374 \\
12.340\end{array}$ & $\begin{array}{r}+\quad 0.3 \\
+\quad 67.3\end{array}$ \\
\hline $1980 / 81$ & 15.187 & 2.111 & 17.298 & $+\quad 40.2$ \\
\hline $1981 / 82$ & 16.482 & 2.342 & 18.824 & +8.8 \\
\hline $1982 / 83$ & 12.283 & 2.461 & 14.744 & $-\quad 21.7$ \\
\hline $\begin{array}{l}1983 / 84 \\
1984 / 85\end{array}$ & $\begin{array}{l}12.050 \\
10.625\end{array}$ & $\begin{array}{l}2.399 \\
3.369\end{array}$ & $\begin{array}{l}14.449 \\
13,994\end{array}$ & $\begin{array}{l}-\quad 2.0 \\
-\quad 3.1\end{array}$ \\
\hline $1985 / 86$ & 8.816 & 3.621 & 12.437 & -.11 .1 \\
\hline $1986 / 87$ & 4.798 & 2.168 & 6.966 & $-\quad 44.0$ \\
\hline $1987 / 88$ & 6.159 & 2.682 & 8.841 & $\begin{array}{l}26,9 \\
+\quad 2\end{array}$ \\
\hline $1988 / 89$ & 5.007 & 2.633 & 7.640 & $-\quad 13.6$ \\
\hline $\begin{array}{l}1989 / 90 \\
1990 / 91\end{array}$ & 6.288 & 3.049 & $\begin{array}{c}9.337 \\
12.763\end{array}$ & $\begin{array}{l}+\quad 22,2 \\
+\quad 36,7\end{array}$ \\
\hline $1991 / 92^{*}$ & & & 10.997 & $-\quad 13.94$ \\
\hline
\end{tabular}

tahun 1986, yang mencapai titik terendah pada bulan Agustus 1986, yakni US $\$ 9,83$ per barrel. Sejak itu sampai dengan terjadinya Krisis Teluk pada Agustus 1990 harga ekspor minyak kita tak pemah mencapai angka US\$19 per barrel.

Fluktuasi harga minyak dan gas di pasar internasional tersebut secara langsung mempengaruhi penerimaan ekspor Indonesia. Tabel berikut ini menunjukkan nilai ekspor minyak dan gas alam sejak 1969/1970 hingga tahun 1991/1992).

- Perkiraan realisasi 
Namun demikian ada kecenderungan bahwa ketergantungan pada penerimaan minyak ini semakin dapat ditinggalkan. Timbulnya kesadaran yang tinggi akan bahaya penerimaan yang hanya mengandalkan dari satu sektor saja, telah membuat pemerintah melakukan upayaupaya untuk mendorong tumbuhnya sektor-sektor di luar minyak dan gas. Hasilnya cukup dirasakan sekarang.

Kemerosotan dan gejolak harga minyak dunia, tidak terlalu melabilkan pembangunan, karena sektor-sektór lain cukup mampu mengantisipasi dan mengkompensasi penerimaan minyak yang anjlok tersebut. Jika dilihat dari penerimaan ekspor, misalnya, sekarang ini andil minyak bumi sudah dibawah $50 \%$. Padahal sejak 1974 hingga 1986 yang lalu andil minyak dalam ekspor total selalu melampaui angka 50\% (lihat Lampiran 1).

Namun demikian ini tidak berarti bahwa peran hutang luar negeri ini telah semakin kecil. Bantuan luar negeri yang tadinya proporsinya sudah menurun di bawah 50\% dari total, pengeluaran pembangunan, sejak 1986/1987 hingga tahun 1991/1992 kembali berada pada tingkat di atas 50 persen. Bila dilihat nilai absolutnya, misalnya tahun 1991/1992 yang. lalu juga masih tinggi, yakni mencapai Rp. 10,371 trilyun, yang berarti jauh diatas jumlah pengeluaran pemerintah untuk membayar seluruh gaji pegawainya yang ada di dalam dan luar negeri serta tunjangan-tunjangan pegawai lainnya yang tahun itu dialokasikan sebesar Rp. 7,753 trilyun.

Perkembangan nilai absolut hutang luar negeri ini sejak Pelita I (dalam nilai rupiah) hingga tahun 1990/1991 cenderung semakin meningkat. Tahun 1969/70 pinjaman luar negeri tersebut hanya Rp. 91 milyar, dan tahun 1990/1991 sudah membengkak menjadi Rp. 11.289,5 trilyun. Sementara itu, secara proporsional atas total anggaran pembangunan, kecuali dalam dua tahun terakhir ini, perán bantuan luar negeri seakan tidak menunjukkan kecenderungan yang semakin menurun (berkisar 70-81,5\% sejak 1986/87). Sampai tahun anggaran 1990/1991 porsi bantuan luar negeri atas pengeluaran pembangunan ini masih sekitar $70 \%$.

Untuk memberikan gambaran lebih jelas mengenai perkembangan nilai belanja pembangunan pemerintah, serta sumber pembiayaannya sejak Pelita $\mathrm{I}$, dapat dilihat dalam Tabel berikut ini.

Tabel : 2

Pengeluaran Pembangunan 1969/1970-1991/1993

\begin{tabular}{|c|c|c|c|}
\hline \multirow[b]{2}{*}{ Th. Anggaran } & \multirow[b]{2}{*}{$\begin{array}{l}\text { Anggaran Pembangunan } \\
\text { (milyar rupiah) }\end{array}$} & \multicolumn{2}{|c|}{ Dibiayai oleh } \\
\hline & & $\begin{array}{c}\text { Tabungan } \\
\text { Pemerintah } \\
\text { ( \% ) }\end{array}$ & $\begin{array}{c}\text { Bantuan } \\
\text { Luar neğeri } \\
\text { ( \%) }\end{array}$ \\
\hline PELITA I : & • & & \\
\hline $1969 / 1970$ & 118,2 & 23,0 & 77,0 \\
\hline $1970 / 1971$ & 118,2 & 31,9 & 68,1 \\
\hline
\end{tabular}




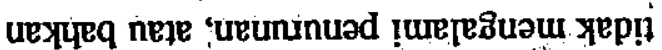

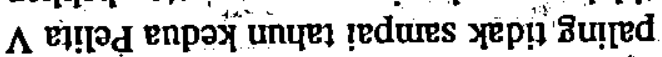

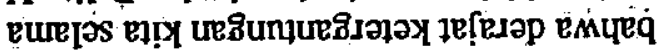

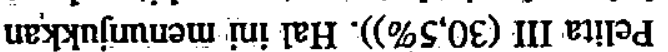

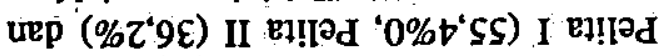

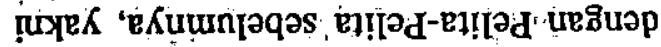
uex̃ uexynfunuatu . "ueunsouequad euep

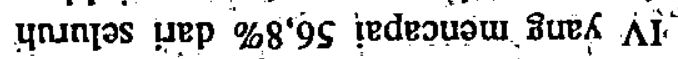

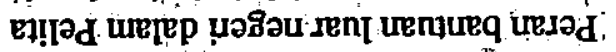

E661 / 2661 NGdV4 بep ч링 : Jequns

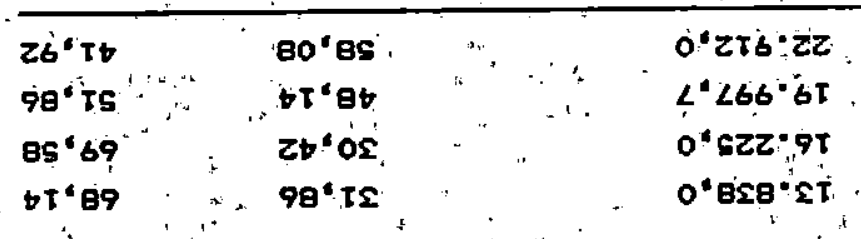

s66T/266T

266T/T6ST

TS6T/066T

OSGT/GËTT

$\therefore$ : $\forall 1$ ìizd

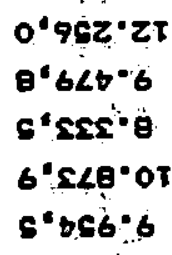

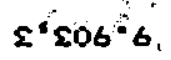
$0<295: 4$

$0 * 6+6=9$

B.0z6"s

T०970:6

$$
\begin{array}{r}
9^{\circ} \mathrm{gt} \\
40^{\circ} \mathrm{Cs} . \\
\angle 6^{\circ} \mathrm{OS} \\
T^{\circ} \angle 9^{\circ} \\
T^{\circ} \mathrm{SO}
\end{array}
$$

$z$ कर

6.92

$90 t z$

$z$ sc

$\bullet \bullet \varepsilon$
8.09

$9^{\circ} \Sigma L$

$6 \mathrm{SL}$

$\theta^{2}+2$

9:59

\section{T/986t.}

8g6T/LB6t

LEST/986T

986T/986T

s86T/686T

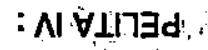

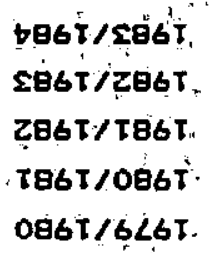

\& III $\forall$ LI7

$6^{\circ} \mathrm{LSG} \mathrm{S}^{\circ} \mathrm{z}$

6L6T/8̂L6T

$8 \angle 6 T / \angle \angle 6 T$

$\angle \angle 6 T / 9 \angle 6 T$

$9 \angle 6 T / 5 \angle 6 T$

$S \angle S T / T \angle G T$

: II $\forall i 17 \exists d$

s'ost

$b \angle 6 T / \Sigma \angle 6 T$

s.oTs

$\varepsilon \angle 6 T / Z \angle 6 T$

कैtน

$2 \angle 6 \mathrm{t} / \mathrm{T} \angle 6 \mathrm{~T}$ 
meningkat jika dibandingkan dengan periode Pelita II dan Pelita III. Walaupun sering bergema pernyataan yang menyatakan bahwa kita akan menurunkan derajat ketergantungan ini, namun angkaangka kuantitatif tersebut menunjukkan bahwa keinginan tersebut hingga tahun 1990/1991 belum mewujud.

\section{Hutang Luar Negeri dalam Tahun Anggaran . 1992/1993}

Bagaimanakah porsi penerimaan dari hutang luar negeri dalam tahun anggaran 1992/1993 ini ? Seperti dikemukakan sebelumnya, hutang luar negeri dalam RAPBN 1992/1993 mengalami penurunan sebesar 7,4\%, yakni dari Rp. 10,371 trilyun menjadi "hanya" Rp 9,6 trilyun. Ada beberapa aspék yang kiranya menarik untuk didiskusikan dari angka-angka hutangluar negeri ini. Dilihat dari nilai nominalnya (maupun riel), maka penurunan hutang luar negeri ini bisa mencerminkan bahwa kita semakin berusaha mengurangi ketergantungan pada hutang luar negeri untuk mengisi "defisit" pada anggaran belanja pemerintah.

Namun penurunan ini juga bisa terjadi karena kekhawatiran kita bahwa hutang yang bisa diperoleh dari luar akan semakin sulit. Adanya signal yang berkali-kali diberikan negara-negara donor sebelumnya, yang akan menurunkan pinjaman lunak untuk Indonesia, telah memaksa untuk tidak terlalu mematok angka terlalu tinggi dalam pos pinjaman luar negeri tersebut. Faktor lainnya adalah karena kesulitan kita dalam menyediakan dana rupiah (counterpart fund) sebagai syarat untuk merealisasikan hutang luar negeri ini. Hutang luar negeri yang dianggarkan dalam tahun 1992/1993, dilihat dari nilai rupiahnya, adalah sedikit lebih besar dibandingkan hutang yang dibuat pemerintah pada tahun anggaran 1988/1989, yakni sebesar Rp 9,9 trilyun.

Sebagaimana diketahui, pinjaman luar negeri ini aslinya diterima dalam bentuk atau diukur dengan mata uang asing keras (hard currencies). Jika kita kurs-kan hutang luar negeri ini, misalnya secara sederhana dengan hanya menggunakan mata uang dollar AS sebagai ukuran, maka nilainya pun semakin menurun. Dalam bentuk dollar (dengan kurs tengah Januari 1991 US $\$ 1$ = Rp 1912), hutang luar negeri yang dianggarkan dalam tahun 1991/1992 adalah US\$ 5,4244 milyar. Sedangkan untuk tahun anggaran 1992/1993 yang disampaikan Kepala Negara (dengan kurs US $\$ 1=$ Rp 1996) ' hutang luar negeri tersebut adalah US\$ 4,8 milyar. Jadi, setelah memperhitungkan perubahan nilai kurs, penurunan yang terjadi bukanlah 7,4\% melainkan sebesar 11,1 persen.

Dengan melihat nilai-nilai uangnya, baik dalam rupiah maupun dollar, jika dikaitkan dengan prinsip kemàndirian kita, maka keadaan yang digambarkan dalam APBN 1992/1993 ini bisa dinilai positif, karena sejalan dengan tekad untuk menjadikan bantuan luar negeri hanya sebagai pelengkap, sebagaimana diamanatkan dalam GBHN. Artinya, dana utama untuk belánja pembangunan harus lebih diutamakan yang sumbernya pada potensi masyarakat Indonesia sendiri. Sumber dalam negeri ini, jika dilihat dari anggaran pembangunan, tercermin dalam nilai tabungan pemerintah, yakni selisih antara penerimaan dalam negeri dengān pengluaran rutin.

Namun demikian kajian terhadap hutang luar negeri ini, bisa pula -- dan 
biasanya dianggap lebih penting -- adalah dilihat dari sejauhmana peran (persentase) bantuan luar negeri tersebut dalam pengeluaran pembangunan. Ini sejalan dengan salah satu prinsip dalam penerapan anggaran belanja kita, yakni prinsip anggaran dinamis, di samping prinsip berimbang dan fungsional. Dalam prinsip anggaran yang dinamis ini dikemukakan bahwa peran (porsi) bantuan luar negeri terhadap anggaran pembangunan harus semakin menurun. Atau, dengan kata lain, porsi tabungan pemerintah haruslah semakin besar. Semakin besar porsi tabungan pemerintah dalam belanja pembangunan, berarti semakin mandiri pula pembangunan kita, khususnya yang dilakukan pemerintah, begitu pula sebaliknya.

Jika melihat hutang luar negeri dalam RAPBN 1992/1993 dibandingkan tahun anggaran sebelumnya maka tampak jelas bahwa porsinya terhadap" anggaran pembangunan semakin kecil (lihat Tabel). Dengan kata lain, sebagian besar proyekproyek investasi pemerintah kian sedikit yang mengandalkan dari dana hutang luar negeri ini. Sementara itu, pengeluaran pembangunan yang dibiayai oleh dana tabungan pemerintah, yang mencerminkan kekuatan dana domestik dalam membangun, semakin meningkat: Porsi hutang luar yang,sebèsar 41,92 persen dari anggaran pembangunan ini, masih lebih besar dibandingkan porsi rata-rata tahunan pada periode Pelita II dan Pelita III, yang masing-masing adalah $36,2 \%$ dan 30,5 persen.

Konsekuensi ekonomis yang dirasakan dengan menurunnya hutang luar negeri ini adalah cendenung memperlambat ekspansi pembangunan yang dapat dilaksanakan dalam tahun anggaran
1992/1993 ini. Keadaan seperti ini sebetulnya tidak perlu terlalu. dikhawatirkan. Alasannya adalah, pertama, dalam jangka panjang penurunan hutang ini akan mengurangi beban pembayaran bunga dan cicilan hutang tersebut. Sejak beberapa tahun terkahir dan sampai sekarang pos pembayaran bunga dan cicilan hutang luar negeri sudah sangat menggerogoti dana pengeluaran rutin. Nilai pos ini bahkan sudah jauh melebihi dari nilai hutang baru yang dibuat! Dengan kata lain sudah terjadi capital outflow atau negative capital inflow of funds sebagai konsekuensi sudah terlalu' besamya hutang luar negeri ini. Atau dengan bạhasa yang lebih sederhana, anggaran ini sudah pada posisi gali lubang tutup lubang, dan lubang yang ditutup ternyata kian membesar...

Alasan kedua, 'penurunan hutang ini dapat memberikan rangsangan bagi kita untuk mengefisienkan pengeluaran dana yang ada dan berupaya mencari sumbersumber pendapatan altematif, seperti menggalakkan ekspor ataupun pariwisata. Dalam rangka efisiensi misalnya dapat dipikirkan bagaimana upaya memperkecil capital output ratio (COR), sehingga setiap rupiah yang diinvestasikan dapat menghasilkan output yang memadai, atau meńcari sektor-sektor yang bisa mendorong laju pertumbuhan ekonomi yang tinggi dengan nilai investasi yang tertentu. Di samping itu, tentu saja kebocoran-kebocoran anggaran belanjan ini - yang oleh Prof.Soemitro pemah dikatakan mencapai $30 \%$ - bisa ditekan kárena adanya tantangan penurunan hutang luar negeri ini.

Pembayaran Bunga dan Cicilan.

Konsekuensi dari besamyá hutang luar negeri yang telah dibuat, adalah 
munculnya kewajiban untuk membayar mengalami peningkatan, sejalan dengan buriga dan cicilan atas hutang-hutang yang meningkatnya hutang yang telah diterima itu. Pembayaran bunga dan cicilan hutang (lihat Tabel 3). ini dari tahun ke tahun juga terus

Tabel: 3

Peranan Pembayaran Bunga dan Cicilan Hutang Luar Negeri

Terhadap Pengeluaran Rutin dan Realisasi APBN.

$1969 / 70$ - 1992/93

.. (dalam milyar rupiah )

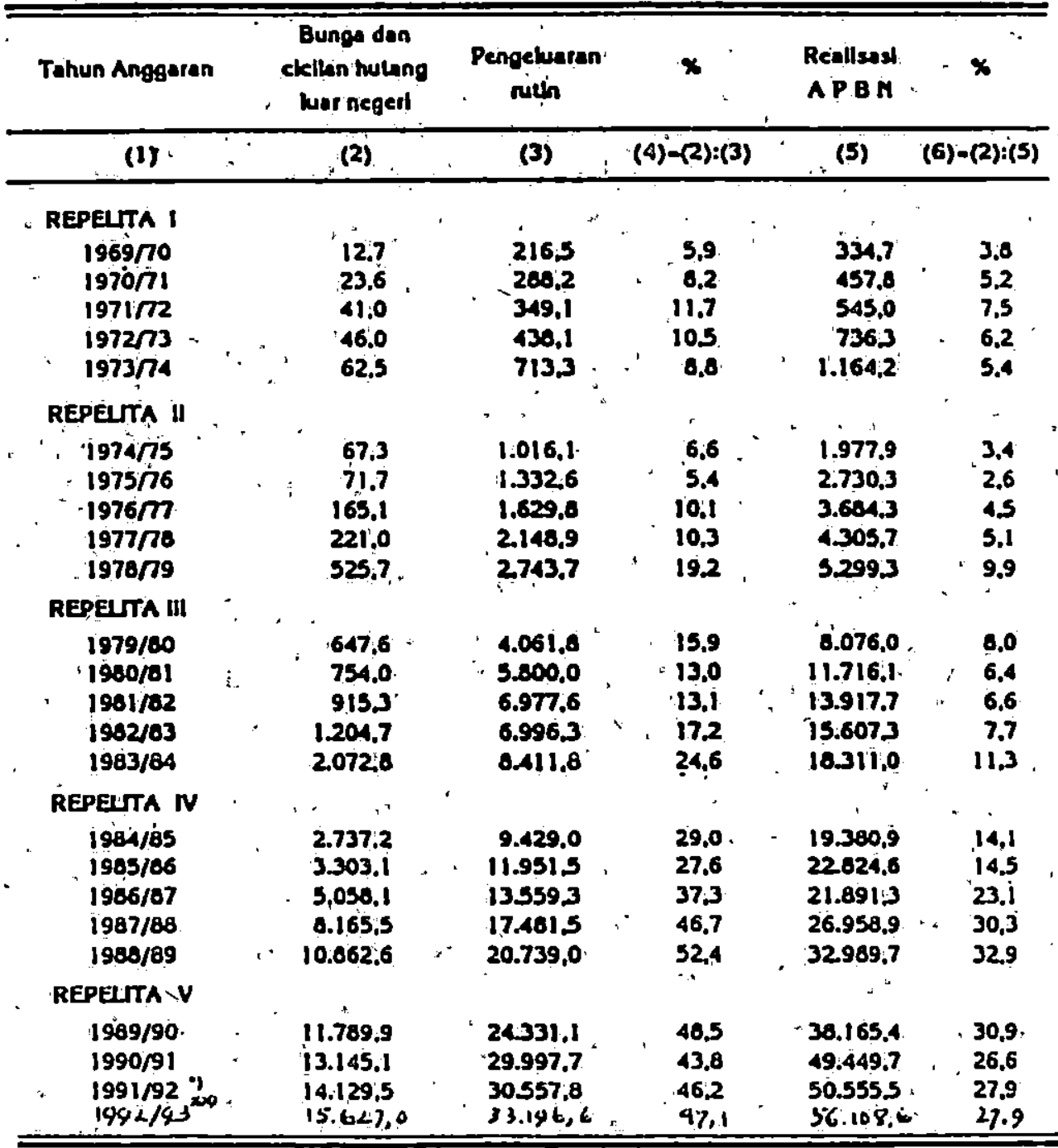

x) APBN

XX) RAPBN 
Dari Tabel ini secara nyata menunjukkan beban pembayaran bunga dan cicilan hutang ini semakin besar menggerogoti pengeluaran rutin pemerintah. Artinya, porsi pos-pos pengeluaran rutin lainnya, seperti belanja pegawai, belanja barang, subsidi daerah otonom ataupun subsidi lainnya, mungkin terpaksa dikurangi untuk memenuhi kewajiban membayar bunga dan cicilan hutang tersebut. Dalam tahun 1992/1993 pos ini dianggarkan sebesar Rp 15,9 trilyun atau menyerap $47,9 \%$ dari seluruh pengeluaran rutin. Secara nominal pembayaran bunga dan cicilan hutang tersebut meningkat $10,6 \%$ dari anggaran tahun lalu. Sedangkan porsinya terhadap total pengeluaran rutin juga lebih tinggi dibandingkan tahun yang lalu, yang "hanya" 47,0 persen. Dengan demikian semakin besamya pembayaran bunga dan cicilan hutang ini memperkuat daya kontraksi yang terjadi pada pos penerimaan. Dengan semakin banyaknya pinjaman dari negara-negara sahabat dan lembaga keungan intemasional itu yang sudah jatuh tempo, maka diperkirakan pada tahun-tahun mendatang akan semakin besar pula dana yang hanus dialokasikan pada pos pengeluaran ini.

\section{P'erkuat Kemandirian}

Apakah dalam waktu-waktu mendatang kemandirian kita dalam membangun ini akan meningkat? Agaknya tidak mudah untuk menjawab pertanyaan tersebut, terlebih dalam perekonomian dunia yang cenderung tidak menentu ini. Namun berbagai statement pemerintah secara tegas sudah mengatakan bahwa pemerintah sudah bertekad untuk memperkuat kemandirian dalam membiayai pembangunan nasional. Pernyataan ini agaknya dikaitkan dengan adanya tanda-tanda akan menurunnya bantuan IGGI untuk Indonesia di masamasa mendatang, disampin juga sebagai ketidak puasān atas tekanan-tekanan yang diberikan negara donor yáng mengaitkan bantuannya dengan Insiden Dili.

Entah karena terpaksa atau sudah menjadi tekad kita, namun sikap untuk meningkatkan kemandirian dalam membiayai pernbangunan tersebut memang sudah sepantasnya dilaksanakan. Amanat rakyat yang tersurat dalam GBHN pun menuntut demikian, menuntut adanya kondisi yang semakin mengandalkan sumber-sumber dana sendiri untuk pembanguan ini. Artinya memobilisasi berbagai potensi yang ada di dalam negeri untuk menggantikan sumber luar tersebut sudah seharusnya digalakkan. Rencanarencana pembangunan pun dibuat dengan melihat lebih banyak pada kemampuan dana sendiri tersebut.

Oleh karena itu kalaupun nanti bantuan-bantuan dari negara donor benarbenar diturunkan, sepantasnya kita tidak perlu mencari dana hutang pada sumber lainnya, yang bahkan lebih berat persyaratannya. Pinjaman dari IGGI adalah pinjaman berbunga murah dan bersyarat lunak. Karena itu pinjaman antar negara atau dari lembaga-lembagá keuangan internasional nonprofit ini diburu banyak negara Dunia Ketiga. Dan pinjaman inilah yang disyaratkan akan menurun, baik karena alasan kemampuan yang terbatas dari donor maupun karena. pertimbangan bahwa Indonesia sudah semakin maju sehingga bantuan yang diterimanya perlu diturunkan agar negara lain yang lebih miskin bisa lebih banyak mendapat pinjaman mereka. 
Keadaan mungkin akan meningkatkan ketergatungankita kalau pada akhimya bantuan IGGI yang diisyaratkan menurun ini pada masa yang akan datang digantikan dengan pinjaman-pinjaman dari bank-bank komersial dengan tingkat bunga tinggi. Kemungkinan menurunnya pinjaman lunak dari IGGI ini paling tidak memberikan "signal" kepada kita bahwa pada tahun-tahun berikutnya pinjaman lunak ini semakin sulit. Oleh karena itu, jika súdah bertekad untuk menurunkan kemandirian, maka jalan keluarnya tidaklah mencari sumber altematif dari luar negeri yang lebih berat beban pembayarannya. Mobilisasi sumbersumber dalam negeri, serta membuat rencana pembangunan yang realistis dengan sumber-sumber penerimaan yang mungkin didapat dengan tidak harus menanggung beban bunga tinggi, merupakan hal yang agaknya perlu mendapat perhatian utama.

\section{DAFTÁR PÚSTÁKA}

Dornsbush, Rudiger dan Fischer, Stanley, Macro Economics, McGraw-Hill, Inc., Singapore; 1983.

Hamid, Edy Suandi, "Masalah Hutang Luar Negeri Indonesia", makalah pada Seminar On Economic Current Issues yang diselenggarakan oleh' Jurusan Ilmu Ekònomi dan Studi Pembangunan FE UII, Yogyakarta, 1991

-..--.-, "Analisis RAPBN 1992/1993", Kedaulatan Rakyat 14 - 15 Januari 1992, Yogyakarta, 1992.

Rizal Ramly, "Hutang Luar Negeri Indonesia : Kontraksi dan Beban.Ekonomi" dalam PRISMA Nomor 9/XX/September 1991, LP3ES, Jakarta, 1991. 
Lampiran 1

\author{
* Tabel
}

TABUNGAN PEMERINTAH, 1969/70 - 1991/92

(dalam milyar rupiah )

\begin{tabular}{|c|c|c|c|c|c|c|c|c|c|c|c|c|}
\hline Tahun Angguran & & & . & & & Jumbah & $\therefore$ & . & . & & $\begin{array}{l}\text { Kenalkan ' } \\
\text { Penurunori : }\end{array}$ & 1. \\
\hline - & - & & $\therefore$ & ? & & & . & & & . & i'. & \\
\hline REPECITA I & & & $\therefore$ & & 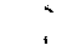 & & $\therefore$ & & & & . & \\
\hline 1969770 & . & & $\because$ & 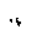 & & 27.2 & s & & & & & \\
\hline , & & & & & & 56,4 & & & & & 29.2 & . \\
\hline $1971 / 72$ & . & & $\therefore$ & & & 78,9 & & $\therefore$ & & & 22,5 & $\cdot$ \\
\hline $1972 / 73$ & & & & , & &, 152.5 & & & & & 73.6 & \\
\hline $1973 / 74$ & & & & & & 254.4 & & & & & . $\quad 101.9$ & \\
\hline & & 1 & & & & . & & & : & & .. & $\checkmark$ \\
\hline REPELTTA I & & & & & & . & & & & & 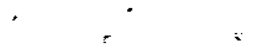 & $\because$ \\
\hline ' 1974/75 & & & & & & 737.6 & , & & & & - $\quad 403.2$ & \\
\hline $1975 n 6$ & , & - & & 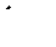 & ? & $\quad 909,3$ & & . & & & - $\quad 171.7$ & \\
\hline $1976 / 77$ & & v & & & ' & 1.276 .2 & & & & & - 360,9 & - \\
\hline $1977 / 76$ & & & & . & . & $1.386,5$ & & . & & , & - 1103 & \\
\hline $1978 / 79$ & & . & & 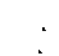 & & 1.522 .4 & ; & & & & $\because \quad 133.9$ & \\
\hline REPEITA IU & & ' & & 1 & & & & & & & ". & \\
\hline $1979 / 80$ & & & & & & 2.635 .0 & & & & & 1.112 .6 & \\
\hline $1980 / 01$ & & & & & & 4.427 .0 & $:$ & & & & 1.792 .0 & \\
\hline $1,981 / 82$ & . & & . & & & 5.235 .0 & & & & & - $\quad 008,0$ & \\
\hline $1902 / 03$. & · & & & + & & 5.422 .0$. & & & & & - $\quad 187.0$ & \\
\hline $1903 / 24$ & & & & : & & 6.020 .9 & & & & & - $\quad 598.9$ & \\
\hline & r & & 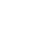 & & & , & & & - & & $\cdot$ & \\
\hline $\begin{array}{l}\text { REPEITA N } \\
\text { 1984/85 }\end{array}$ & & . & & & & & & & & & & \\
\hline $\begin{array}{l}1984 / 85 \\
1905 / 06\end{array}$ & . & & . & & & $6.476,5$ & $\because$ & & & & 455,6. & \\
\hline $1986 / 07$. & & . & & : & & $\begin{array}{l}7,301,3 \\
2.581 .3\end{array}$ & . & 1 & . & & $\begin{array}{r}824.0 \\
-\quad 4720.0\end{array}$ & \\
\hline $1967 / 88$ & 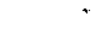 & & & & & 3.321 .0 & . & & . & & $\begin{array}{r}-7.720 .0 \\
-\quad 740.5\end{array}$ & \\
\hline $1988 / 09$ & & & & & . & 2.265 .3 & & & & & -1.056 .5 & \\
\hline REPELTSA $V$ & $\because$ & & & ' & & & & $\therefore$ & & - & $\therefore$ & \\
\hline $1989 / 90$ & . & & & : & & $4.408,7$ & & & & . & - 2.143 .4 & \\
\hline $1990 / 91$ & & & .5 & & & 9.548 .7 & & & & & - $\mathbf{5 . 1 4 0 . 0}$ & \\
\hline $1991 / 92^{\prime \prime}$ & . & & $\therefore$ & : & & $9.626,2$ & . &. & & 1 & - $\quad 77.5$ & \\
\hline
\end{tabular}

๑. APि В 
Lampiran 2

Tabel

HATGA EKSPOR MINYAK BUMI INDONESLA

(dalam US \$ per barel)

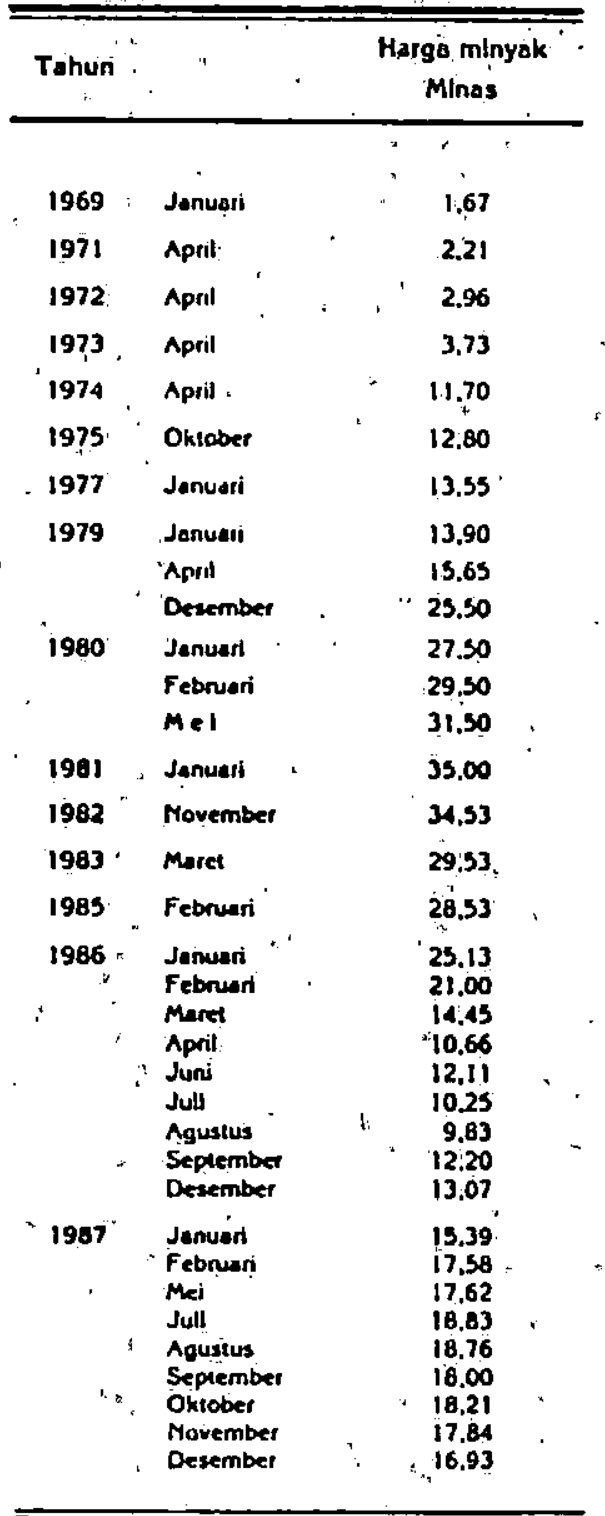

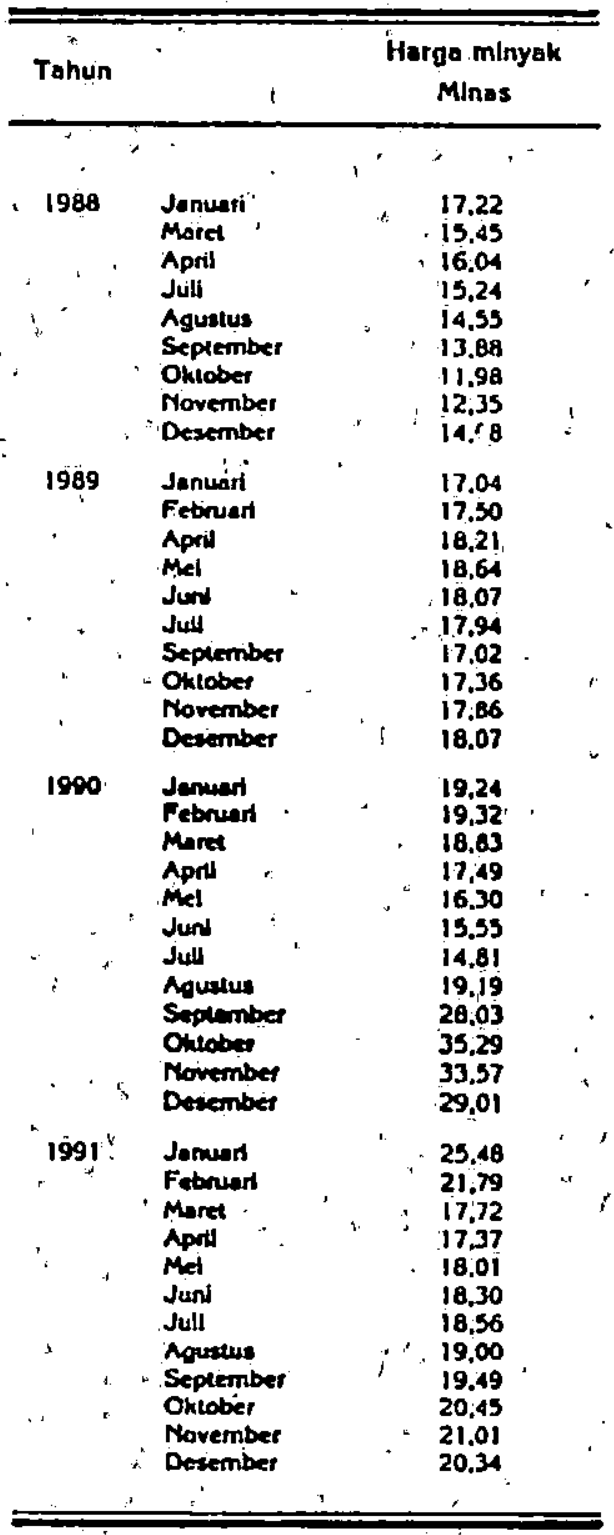


Lampiran 3

Tabel

NILAI EKSPOR, 1969/70 - 1991/92

(dalam juta US \$)

\begin{tabular}{|c|c|c|c|c|c|c|c|c|c|c|}
\hline $\begin{array}{l}\bar{T} \text { a h u n } \\
\text { angagarañ }\end{array}$ & & Migas & & $\%$ & Bukān migas & $x$ & & Jumbh & & $x$ \\
\hline (1) & $\therefore$ & (2) & & (3) & $(4)$ & $(5)$ & (6) & $-(2)+($ & (4) $)^{+}$ & $(7)$ \\
\hline . & & & & . & & & & & & $\therefore$ \\
\hline $1969 / 70$ & & 384 & & 36.8 & 660 & 63.2 & 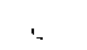 & 1.044 & & 100 \\
\hline $1970 / 71$ & & 443 & & 36.8 & .761 . & 63.2 & e & 1.204 & r & 100 \\
\hline $1971 / 72$ & & 590 & & 42,9 & 784 & 57.1 & & 1.374 & , & 100 \\
\hline $1972 / 73$ & 4 & 965 & & 49.8 & $974^{\circ}$ & .50 .2 & & 1.939 & & 100 \\
\hline $1973 / 74$ & & 1.708 & & 47.3 & 1.905 & 52.7 & & 3.613 & & 100 \\
\hline $1974 / 75$ & & 5.153 & $r$ & 73 & 203 & & & & & \\
\hline $1975 / 76$ & & 5.273 & . & $\begin{array}{l}7.8 \\
73.8\end{array}$ & $\begin{array}{l}2.033 \\
873\end{array}$ & $\begin{array}{l}28,3 \text {, } \\
262\end{array}$ & & 7.186 & & 100 \\
\hline $1976 / 77$ & & 6.350 & & i 68,9 & 2.863 & $\begin{array}{l}20,2 \\
31.1\end{array}$ & & $\begin{array}{r}1.146 \\
-9.213\end{array}$ & g & $\begin{array}{l}100 \\
100\end{array}$ \\
\hline ig7?7/78 & & 7.353 & & 67.7 & 3.507 & 32.3 & & 10.860 & & 100 \\
\hline $1978 / 79$ & & 7.374 & $\therefore$ & 65.0 & 3.979 & 35.0 & & 11.353 & & 100 \\
\hline $1979 / 80$ & - & 12.340 & r & 66.7 & 6.171 & 33.3 & & 18.511 & & 100 \\
\hline $1980 / 81$ & * & $17: 298$ & & 75.6 & 5.587 & 24,4 & & 22.885 & & 100 \\
\hline $1981 / 82$ & & 18.824 & & 81.9 & 4.170 & 18.1 & 1 & 22.994 & , & 100 \\
\hline $1982 / 83$ & & 1.4 .744 & • & $79: 0$ & 3.928: & 21,0 & ' & 18.672 & & 100 \\
\hline $1983 / 84$ & . & 14.449 & & 72,9 & 5.367 & 27.1 & & 19.816 & & $100^{\prime}$ \\
\hline . & & & $\therefore$ & & 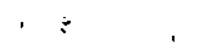 & & & 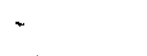 & & , \\
\hline ' 1984/85 & & 13.994 & & 70.3 & 5.907 & 29.7. & & 19.901 & & 100 \\
\hline $1985 / 86$ & & 12.437 & & 66.8 & 6.175 & 33,2 & & 18.612 & i" & 190 \\
\hline $1986 / 87$ & & 6.966 & & 50,9 & 6.731 & 49,1 & & $13: 697$ & & 100 \\
\hline $1987 / 88$ & & 8.841 & & 48.2 & 9.502 & 51.8 & & 18.343 & & 100 \\
\hline $1988 / 89$ & & 7.640 & & 38,5 & $\cdot 12.184$ & 61.5 & & 19.824 & $:$ & 100 \\
\hline * & & 、 & & . & , & & & + & & \\
\hline $1989 / 90$ & & 9.337 & & 39.2 & 14.493 & 60.8 & & 23.830 & & 100 \\
\hline $1990 / 91$ & & 12.763 & & 45.4 & 15.380 & 54,6 & . & 28.143 & . & 100 \\
\hline \multirow[t]{2}{*}{$1991 / 92 " 11$} & & 10.997 & & 37.6 & 18.225 & 62,4 & & 29.222 & ? & .100 \\
\hline & & & & & & & & . & & \\
\hline
\end{tabular}

1) Perkireen revisioss 
